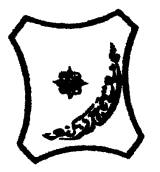

Bayero Journal of Pure and Applied Sciences, 11(1): 220 - 222

ISSN 2006 - 6996

\title{
ENTEROBACTERIAL CONTAMINATION OF SOME MEAT PRODUCTS COMMERCIALLY AVAILABLE IN KADUNA METROPOLIS
}

\author{
${ }^{1 *}$ Muhammad Yusha'u, ${ }^{1}$ Muhammad I. Umar, ${ }^{2}$ Awwali Tati and ${ }^{3}$ Abimbola A. Orukotan \\ ${ }^{1}$ Department of Microbiology, Bayero University, Kano - Nigeria \\ ${ }^{2}$ Department of General Studies, Sani Zangon Daura School of Health Technology, Daura, Katsina \\ State \\ ${ }^{3}$ Department of Microbiology, Kaduna State University, Kaduna - Nigeria \\ *Correspondence author: mryushau@gmail.com
}

\section{ABSTRACT}

A total of 171 processed meat products which include balangu, tsire, kilishi and dambun nama sampleswere collected from different locations in Kaduna metropolis. The sample were were blended, serially diluted and subjected to isolation and identification of pathogenic bacteria via standard biochemical tests. The result of this study showed the presence of 128 bacterial isolates including; Escherichia coli (38), Klebsiella pneumonia (20), Salmonella typhi (18), Serratia marcescens (12), Citrobacter freundii(15) and Proteus vulgaris (25) with E. coli being the most predominant (29.69\%) bacteria isolated. The high occurrence rate of pathogenic bacteria in the meat products sold in Kaduna metropolis is of great public health concern as the products are commonly used by the general public.

Keywords: Occurrence, Enterobacteriaceae, Meat products, Kaduna

\section{INTRODUCTION}

Meat is an edible animal flesh which comprises principally of muscular tissue and the internal organs called viscera such as heart, liver, kidney, intestine and bladder. Because of the enormous value of the meat in the diet, there exist large markets for meat and meat products worldwide at varying financial value hence their demand increase day by day across the globe (Adams and Moss, 1999).

Meat products are obtained when raw or preserved meat are altered in form by grinding, pressing, drying and other processes then augmented in flavor by smoking, spicing or blending with other food. These meat products are subjected to combination of several basic processing steps before reaching their final form. Therefore meat products are also termed processed meat (Gibbons et al., 2006).

There exist different types of meat products ranging from industrially processed ready to eat meat such as bulangu (roasted meat), kilishi, tsire, dambun nama (shredded form).

Microorganisms that occur in meat and meat products most times are responsible for food borne illness. The source of Enterobacteriaceae on meats was shown to be associated with the meat handling and work surfaces at the packing plants and retail facilities. Escherichia coli biotype I and Serratia liquefaciens were determined at all stages of meat (Adams and Moss, 1999). This research is prompted by the existence of many meat product selling outlets which are patronized by many urban dwellers as well as the apparent lack of control which predisposes the consumers to health hazard, hence there is need to carry out a research to ascertain the sanitary quality of the meat products.

\section{MATERIALS AND METHODS \\ Study Area}

The area studied is meat product selling outlets in Kaduna metropolis (Kawo, Malali, Angwan shanu, Angwan sarki and Central Market).

Sample Collection

The samples include various types of ready to eat meat product from different selling joints in Kaduna metropolis. Sample collected were transported to microbiology laboratory for analysis under aseptic condition.

\section{Homogenization}

Twenty five gram (25g) of the sample meat product was homogenized with $225 \mathrm{ml}$ buffered peptone water (Lamrnerding, 1997).

Isolation of bacteria

One milliliter of the homogenized sample was transferred into a petri-dish and cooled molten MacKonkey agar poured into the petri-dish and then gently shaken. This was followed by inaubation at 37 degree for 24 hours (FAO, 1979).

Gram Staining

Gram staining was carried out on the isolates to differentiate the Gram negative from the Gram positive bacteria (Cheesebrough, 2005). 
Biochemical test for characterization of bacteria

\section{Citrate Utilization Test}

A mass of $24.28 \mathrm{~g}$ of Simon citrate agar was dissolved in one litre of distilled water and sterilized. The agar medium was then inoculated using sterile needle. This was incubated at $37^{\circ} \mathrm{C}$ for 24 hours (Cheesebrough, 2005).

\section{Kligler Iron Agar}

The agar slant was streaked and the butt was stabbed with the test organism and incubated at $37^{\circ} \mathrm{C}$ for 24 hours (Cheesebrough, 2005).

Urease test

Twenty four hours culture of each isolates was inoculated onto a slanted urea agar medium by streaking the slant and stabbing the butt(Cheesebrough, 2005).

Indole Test

Media used are peptone water. The test is carried out by adding KOVAC's reagent to a 24 hours culture and observing for the appearance of red coloured ring on the surface layer within 10minutes.

Methyl red test

The test organism is inoculated in methylredVogesproskauer (MR-VP) broth and incubated at $37^{\circ} \mathrm{C}$ for 2-5days. This is followed by the addition of five drops of methylred indicator, mixwell and results are read immediately. Red colour is positive while yellow colour is negative.

Voges-proskauertest

The organism is inoculated in glucosephosphate (MR-VP) broth and incubated at $37^{\circ} \mathrm{C}$ for 48hours. This is followed by the addition of $1 \mathrm{ml}$ of $40 \% \mathrm{KOH}$ and $3 \mathrm{ml}$ of a-naptholin absolute alcohol. Positive result is indicated by the formation of pink colour within 2-5minutes deepening to crimson colourin 30 minutes.

\section{RESULTS}

Bacteriological analysis of meat products revealed the occurrence of 128 bacterial organisms from the total 171 samples processed which account for bacterial contamination of the product at the rate of $74.85 \%$ (Table 2). Occurrence of the specific bacterial specie was determined after subjecting the isolates to biochemical characterization using standard tests (Table 1) where $E$. coli was observed to have the highest rate of occurrence (29.69\%) (Table 3).

Table 1: Distribution of isolated bacteria based on biochemical reactions

\begin{tabular}{|c|c|c|c|c|c|c|}
\hline Test/Org & Citrobacterspp & E. coli & Klebsiellaspp & Proteus spp & Serratiaspp & $\begin{array}{l}\text { Salmonella } \\
\text { spp }\end{array}$ \\
\hline Glucose & + & + & + & + & - & + \\
\hline Lactose & $\ldots .+$ & + & + & - & $+/-$ & - \\
\hline Urea & $+/-$ & - & Slow & + & $+/-$ & - \\
\hline Citrate & + & - & + & $+/-$ & - & $+/-$ \\
\hline Motility & + & + & - & + & - & + \\
\hline Indole & - & + & - & $+/-$ & - & - \\
\hline Slope & $\mathrm{R} / \mathrm{Y}$ & $Y$ & $Y$ & $\mathrm{R}$ & $\mathrm{R}$ or $\mathrm{Y}$ & $\mathrm{R}$ \\
\hline Butt & $Y$ & $Y$ & $Y$ & $Y$ & $Y$ & $Y$ \\
\hline $\mathrm{H}_{2} \mathrm{~S}$ & $+/-$ & - & - & + & - & + \\
\hline Gas & + & + & + & + & $+/-$ & $+/-$ \\
\hline Number & & & & & & \\
\hline Identified & 15 & 38 & 20 & 25 & 12 & 12 \\
\hline
\end{tabular}

Table 2: Overall Occurrance of Bacterial Isolates

\begin{tabular}{llll}
\hline S/no & Isolates & Number obtained & \%occurrence \\
\hline $\mathbf{1}$ & Escherichia coli & 38 & 31.2 \\
$\mathbf{2}$ & Klebsiellapneumoniae & 20 & 16.4 \\
$\mathbf{3}$ & Salmonella typhii & 12 & 09.8 \\
$\mathbf{4}$ & Serratiamarcescens & 12 & 09.8 \\
$\mathbf{5}$ & Citrobacterfreundii & 15 & 12.3 \\
$\mathbf{6}$ & Proteus vulgaris & 25 & 20.5 \\
& Total & 122 & 100.00 \\
\hline
\end{tabular}


Special Conference Edition, November, 2018

Table 3: Overall distribution of bacterial in meat products analyzed

\begin{tabular}{lccclllll}
\hline $\begin{array}{l}\text { Meat } \\
\text { Type }\end{array}$ & NP & NI & E. coli & $\begin{array}{l}\text { K. } \\
\text { pneumoniae }\end{array}$ & C. freundii & $\begin{array}{l}\text { S. } \\
\text { marcescens }\end{array}$ & S. typhii & $\begin{array}{l}\boldsymbol{P} . \\
\text { vulgaris }\end{array}$ \\
\hline Tsire & 42 & 29 & $10(34.5 \%)$ & $6(20.7 \%)$ & $3(10.3 \%)$ & $2(6.9 \%)$ & $3(10.3 \%)$ & $5(17.2 \%)$ \\
Killishi & 52 & 44 & $13(29.5 \%)$ & $8(18.2 \%)$ & $6(13.6 \%)$ & $5(11.4 \%)$ & $5(11.4 \%)$ & $7(15.9 \%)$ \\
Balangu & 43 & 25 & $9(36.0 \%)$ & $3(12.0 \%)$ & $4(16.4 \%)$ & $3(12.0 \%)$ & $3(12.0 \%)$ & $3(12.0 \%)$ \\
Dambun & 34 & 24 & $6(25.0 \%)$ & $3(12.5 \%)$ & $2(8.3 \%)$ & $2(8.3 \%)$ & $1(4.2 \%)$ & $10(41.7 \%)$ \\
Nama & 171 & 122 & $38(31.2 \%)$ & \begin{tabular}{l} 
20(16.4\%) \\
\multicolumn{7}{l}{ Key: NP = Number processed; NI = Number Isolated }
\end{tabular} \\
\hline
\end{tabular}

\section{DISCUSSION}

A total of one hundred and twenty two (122) bacteria were isolated which is equivalent to $74.85 \%$ contamination rate. The rate at which the products are contaminated is high which may be due to the unhygienic practices especially cross contamination from the hands of the sellers as well as the knives used. This poses a threat to the consumers as it indicates the possibility of transfer of infectious agents from the products to healthy individuals. This can result in possible outbreak of food borne infection. The results differ with that reported by Shamsuddeen and Yusha'u (2006) where they reported 100\% contamination rate among both raw and processed meat sold around red bricks (Jan Bulo) area of Kano metropolis.

Biochemical identification of the bacterial isolates revealed the occurrence of the following; Escherichia coli 38(31.2\%), Klebsiella pneumoniae 20 (16.4\%), Salmonella typhi12 (9.8\%), Serratia marcescens12 (9.8\%), Citrobacter freundii15 (12.3\%) and Proteus vulgaris 25 (20.5\%). This indicated that $E$. coli as had the highest occurrence rate of $31.02 \%$ while Salmonella typhi and Serratia marcescens had the least occurrence rates of $9.38 \%$ respectively. This indicates possible contamination of the products from fecal sources. The result highlights the possibility of infection with multitude of human pathogens that may lead to prolonged hospital stay. The results vary with that reported by Shamsuddeen and Yusha'u (2006) where they reported Staphylococcus aureus to have 100\% contamination rate while $E$. coli had $60 \%$

\section{REFERENCES}

Adams, M.R., and Moss, M.O. (1999): Food Microbiology. The Royal Society of Chemistry. Thomas Graham house. Service park, Cambridge, UK. Pp192-202

Bolton, F. J., Crozier, L. and Williams, J. K. (1996): Isolation of $E$. coli 0157 from meat products. Lett. Appl. Microbiol. 23: 317-321.

Cheesbrough, M. (2005): District laboratory practice in tropical countries, part2. Cambridge university press, UK Pp38, 65, 70, 395.

Food and Agriculture Organization of the United Nations FAO (1979). Manuals of food quality control 4, Microbiological analysis, 18-34. contamination rate among processed meat in Kano. It however corroborate with the report of Bolton et al. (1996) where they showed the presence of $\mathrm{E}$. coli in retail meat products especially beef products.

The results of this study indicated that Kilishi is the most contaminated $44(36.1 \%)$ while Dambun nama is the least contaminated $24(19.7 \%)$ among the meat products. This may not be unconnected to the fact that Kilishi is allowed to stay exposed for a long period of time in the cause of preparation and require less heat than the other products. It therefore incriminates Kilishi as the cheap vehicle for transmitting food-borne pathogens more than the other meat products. This agrees with Bolton et al. (1996) who reported bacterial contamination of retail beef products.

\section{CONCLUSION}

From the research conducted, it can be concluded that pathogenic bacteria exist at high rates in meat products sold in Kaduna metropolis which can constitute threat to the public health.

\section{Recommendations}

From the results obtained in this study, it is recommended that the appropriate authority should engage in public enlightment on:

(i) Improved personal hygiene of the meat handlers

(ii) Aseptic techniques during processing and handling

(iii) Regulations to limit of the selling outlets

Gibbons, I, Adesiyun, A, Seepersasingh, N. and Rahman, S. (2006). Investigation for possible source(s) of contamination of read to eat meat products with Listeria spp and other pathogens in a meat processing plants Trinidad. Intl journal of food microbiology 23: 359-66.

Lamrnerding, A.M. (1997). An overview of microbial food safety risk assessment. Journal of food protection; 6

Shamsuddeen, U. and Yusha'u, M. (20016): Bacteriological quality assessment of meat sold around red bricks (Janbulo) quarters in Kano. Biological and Environmental Journal for the Tropics 3(4): 95-98. 